\begin{tabular}{llr} 
KULTURA & POLSKA A KADEMIA NAUK & ISSN 0023-5172 \\
i & KOMITET SOCJOLOGI & \\
SPOLECLENSTWO & $\begin{array}{l}\text { INSTYTUT STUDIÓW POLITYCZNYCH } \\
\text { 2020, nr 3 PROJEKTOWANIE DZIECIŃSTWA }\end{array}$ & \\
\hline
\end{tabular}
$\begin{array}{lllllllll}A & R & T & Y & K & U & \ddots & Y\end{array}$
I
$\begin{array}{llllllll}\mathrm{R} & \mathrm{O} & \mathrm{Z} & \mathrm{P} & \mathrm{R} & \mathrm{A} & \mathrm{W} & \mathrm{Y}\end{array}$

ALEKSANDRA ZALEWSKA-KRÓLAK

Instytut Stosowanych Nauk Społecznych Uniwersytetu Warszawskiego

\title{
OBSERWATORIUM SZTUKI DLA DZIECKA JAKO KOLAŻ POLIFONICZNYCH PROJEKTÓW DZIECIŃSTWA
}

Za projektowaniem wydarzeń artystycznych dla dzieci stoją założenia dotyczące tego, kim są dzieci. Nowa socjologia dzieciństwa (new sociology of childhood) zwraca uwagę na to, że dzieciństwo jest konstruktem społecznym, kontekstualnym, nieustannie modyfikowanym (James, Prout 1997; Corsaro 2015; Mayall 2013). Sklejanie, dopasowywanie, zestawianie ze sobą spostrzeżeń, idei, odczuć to praca, którą wykonał zespół Obserwatorium festiwalu 22. Biennale Sztuki dla Dziecka. Chciałabym ukazać wielogłosowość opinii wynikających z subiektywnych znaczeń, które tworzą kolaż. Każdy element ma źródło w doświadczeniach będących składnikami jednostkowych trajektorii biograficznych. Zamierzam przedstawić potencjał tej polifoniczności. Tworzenie kolażu implikuje różnorodność, ale pozwala także na niewartościowanie elementów, stawianie ich na równi, a zarazem pokazywanie ich odmienności.

Przedstawiam tu wnioski płynące $z$ moich badań Obserwatorium Sztuki dla Dziecka, integralnej części projektu Biennale Sztuki dla Dziecka. Zadaniem Obserwatorium jest przyglądanie się wszystkiemu, co dzieje się podczas festiwalu oraz rozmowa na ten temat. Na Biennale pojechałam jako obserwatorka, moja rola była jasna i jawna.

Adres do korespondencji: aleksandra.zalewska@uw.edu.pl; ORCID: 0000-0002-8503$-4845$ 
$\mathrm{Na}$ początku opisuję tu ideę Biennale. Staram się ukazać procesualność tego projektu i jednocześnie stworzyć tło dla wniosków płynących z moich badań. Następnie przedstawię ideę Obserwatorium, które różnie działa na różnych etapach Biennale, mając jednak ten sam cel - stworzenie platformy wymiany wiedzy na temat sztuki dla dziecka. Podchodzę do badań zgodnie ze wskazówkami Herberta Blumera (2007) — zaczynam od eksploracji. Podążam za założeniami, których dostarcza podejście fenomenologiczne, i obserwując zwracam uwagę na wiedzę potoczną, subiektywne znaczenia. Egzemplifikacją wielogłosowości w debatach prowadzonych przez zespół Obserwatorium jest graf, który przedstawia zawiłość indagacji związanych ze sztuką dla dziecka ${ }^{1}$. Na jego podstawie wskazuję szanse i ograniczenia gromadzenia wiedzy przez twór, jakim jest Obserwatorium.

\section{BIENNALE SZTUKI DLA DZIECKA JAKO PROJEKT}

Biennale Sztuki dla Dziecka to interdyscyplinarny festiwal, który odbywa się w Poznaniu od 46 lat. Jego korzenie można odnaleźć w wydarzeniach z 1973 roku, będących połączeniem Konfrontacji Teatralnych oraz Przeglądu Filmów dla Dzieci. Myślą, która od początku towarzyszyła zdarzeniu??, było stworzenie instytucji stanowiącej bazę organizacyjną festiwalu - miejsca, które w sposób ciągły i systematyczny zajmowałoby się sztuką dla najmłodszych, inspirowało i upowszechniało wartościowe, nowatorskie postawy artystyczne i edukacyjne, tworząc warunki dla ich społecznego oddziaływania ${ }^{2}$. Ta idea urzeczywistniła się w 1974 roku w Poznaniu, kiedy Minister Kultury i Sztuki powołał Ogólnopolski Ośrodek Sztuki dla Dzieci i Młodzieży — instytucję kultury o charakterze narodowym. Obecnie (od 1999 roku) ośrodek nosi nazwę Centrum Sztuki Dziecka w Poznaniu i jest instytucją samorządową, czyli podlega Wydziałowi Kultury Urzędu Miasta. Już w zmianie nazwy instytucji widać zwrot odnoszący się bezpośrednio do konstruktu, jakim jest dzieciństwo. W nowej wersji znika przyimek „dla”. Na stronie instytucji możemy przeczytać „Dziecko to dla nas partner w odbywającej się poprzez sztukę, mądrą zabawę i rozrywkę rozmowie o sprawach ważnych" ${ }^{3}$. Postawienie akcentu na sprawczość dzieci wskazuje na docenienie ich kompetencji jako aktorów społecznych. Jest też urzeczywistnienie praw dzieci opisanych w Konwen-

\footnotetext{
${ }^{1}$ Graf można znaleźć na stronie 93 katalogu 22. Biennale (https://drive.google.com/file/ d/1XqWTJeAa2m2JIB3q18qVS6cTjlPvz5Ab/view).

${ }^{2}$ Zob. na stronie Centrum Sztuki Dziecka (https://csdpoznan.pl/o-nas).

3 Tamże.
} 
cji Praw Dziecka. Ukazuje, że nie tylko interakcja z dziećmi jest istotą działań instytucji, ale także współudział dzieci.

Zapoznając się $z$ historią Centrum dowiadujemy się, że kontekst społeczno-kulturowy towarzyszący dzieciom i młodzieży w latach dziewięćdziesiątych miał wpływ na zmianę profilu działania instytucji. Przenosimy się tym samym $\mathrm{w}$ stronę jednego $\mathrm{z}$ kamieni węgielnych childhood studies, a mianowicie założenia, że dzieciństwo jest konstruktem społecznym, jest kontekstualne, a zatem także zmienne. „Program Ośrodka, nastawiony dotąd na twórczość "dla dzieci», wzbogacony został o tworzenie «z dziećmi»" ". Projektowanie programów artystycznych stało się partycypacyjne. Partycypację rozumiem tu za Rogerem Hartem (1992) jako proces dzielenia się decyzjami, które mają wpływ na życie jednostki oraz życie wspólnoty, w której ona żyje. Ten przykład ukazuje procesualność modyfikacji głównej idei instytucji. Pierwsze przemiany zostały zapoczątkowane przez obserwacje transformacji zachodzących $\mathrm{w}$ świecie dzieci oraz refleksję związaną z rolą dziecka w sztuce. Dopiero dokonane na ich podstawie zmiany $\mathrm{w}$ działaniu doprowadziły do zmiany nazwy instytucji.

Festiwal Biennale Sztuki dla Dziecka zachował w nazwie przyimek „dla”, co nie oznacza, że nie uwzględnił wzrostu stopnia partycypacji dzieci w sztuce, czego przykładem może być aktualna edycja festiwalu zatytułowana „Spotkanie jako Sztuka”, zwracająca szczególną uwagę na stopień partycypacji dzieci. Z analizy publikacji katalogów Biennale Sztuki dla Dziecka, można wysnuć wniosek, że festiwal jest tylko jednym z elementów całej serii wydarzeń towarzyszących Biennale. Widoczna jest procesualność zamysłu Biennale jako idei, ale również procesualność każdego z projektów, który składa się na ten koncept. Katalogi poszczególnych edycji są numerowane. Ostatni, czyli ten dotyczący festiwalu, w którym brałam udział, nosi numer 22. Każda edycja trwa dwa lata. Projekty rozpoczynają się od pomysłu, który często rodzi się w dyskusjach towarzyszących poprzedniemu Biennale.

Chciałabym zobrazować potencjał badania procesualności projektów, nawiązując do katalogów Biennale Sztuki dla Dziecka, a w szczególności katalogu 22. Biennale. Uzasadnieniem tej decyzji jest $z$ jednej strony założenie, że ostatni katalog ukazuje to, co przez wszystkie lata udało się wypracować $\mathrm{w}$ ramach Biennale - pewną formę pracy i myślenia o festiwalu sztuki dla dziecka, z drugiej zaś przekonanie, że jest to zabieg, który pozwoli mi zobrazować kontekst działania Obserwatorium, jego polifoniczność wynikającą z różnorodności doświadczeń. Katalog ten uka-

4 Tamże. 
zuje poszczególne etapy pracy nad dwuletnim projektem 22. Biennale. Pierwszym wydarzeniem jest tzw. półmetek, którego celem jest zaprezentowanie widzom rezultatów pracy nad dotychczasowymi działaniami artystycznymi. To premierowe spotkanie z publiką jest dla twórców inspiracją do dalszej pracy nad końcowym efektem. Kolejnym wydarzeniem jest już sam festiwal. W poszczególnych katalogach można zapoznać się z opisem każdego $z$ działań artystycznych, jakie miały miejsce podczas danego festiwalu. Jest to skarbnica wiedzy ukazująca logikę, która przyświecała przez lata Biennale Sztuki dla Dziecka a także założenia dotyczące tego, kim są dzieci i jak konstruowany jest projekt, którym jest dzieciństwo. Dzięki taki danym można przyjrzeć się temu, jak ewaluował dominujący w myśleniu instytucji projekt dzieciństwa. Na przykład dzięki komunikatowi wskazującemu wiek uczestnika możemy się dowiedzieć, ile lat mają dzieci, do których adresowane są wydarzenia i jakie są to wydarzenia. Ciekawym źródłem informacji są także biogramy osób, które były zaangażowane w poszczególne działania. Czytelnik może się dowiedzieć, kim są $z$ wykształcenia ludzie, którzy projektowali wydarzenia artystyczne, czym się zajmują i gdzie to robią, czasami nawet, jakie są ich pasje. Analizując teksty opisujące wydarzenia, można także zauważyć, jak definiowane jest w nich dziecko oraz jaką rolę pełnią w sztuce dla dziecka. Ze względu na charakter działalności Centrum interesującym wątkiem mogą być zmiany w rozumieniu tego, czym jest edukacja artystyczna, jak powinna wyglądać i kiedy się zacząć.

Ciekawym wyzwaniem badawczym jest próba odpowiedzi na pytanie, w jakim stopniu założenia wynikające $z$ nowej socjologii dzieciństwa urzeczywistniają się $\mathrm{w}$ treściach przedstawianych w katalogu. Na pewno zauważalny jest element szacunku i uznawania sprawczości młodego widza. Na przykład w opisie wystawy „Baza”, której twórczynią była Magda Kreis, podana jest informacja, że odbiorcy, bez podziału na wiek, są zaangażowani $\mathrm{w}$ proces powstawiania dzieł, są zapraszani do działań twórczych. Wiele innych wydarzeń festiwalu zostało opisanych jako interaktywne. Co ciekawe, na temat „(inter)aktywności” Kreis (2017) pisała w poprzednim katalogu — odnosząc się do wydarzeń z 21. Biennale, wskazywała na brak interaktywności wystaw. Wypowiadała się wówczas z perspektywy członkini Obserwatorium. Po dwóch latach, na kolejnym festiwalu Biennale, zaproponowała swoją propozycję wystawy — interaktywną. Informacja dotycząca stopnia potencjalnej partycypacji jest możliwa do zrekonstruowania $z$ tekstów, ale określenie jej poziomu z odwołaniem na przykład do stopnia zaangażowania dzieci za pomocą drabiny Harta (1997) byłoby już trudne. Ciekawym przykładem traktowania dziecka jako kompetentnego 
aktora społecznego, w tym przypadku także artystę, jest informacja zamieszczona w opisie jednej z instalacji tej wystawy — Ławki dla dwojga. Tło obiektu zostało stworzone wspólnie przez artystę oraz jego córkę, czternastolatkę, która uwielbia rysować. „Tata wypłacił jej honorarium za współpracę, którego wysokość Judyta sama ustaliła (Krajewska 2019, s. 42).

Innym tropem badawczym mogłaby być próba odpowiedzi na pytanie: $\mathrm{w}$ jaki dyskurs dzieciństwa wpisują się treści zamieszczone $\mathrm{w}$ katalogu, ponieważ — jak wskazuje Chris Jenks (2008, s. 112-113) — „dziecko, jak inne formy ludzkiego bycia w obrębie naszej kultury, uobecniane jest przez rozmaite formy dyskursu. Dyskursy te nie są ani bezwzględnie konkurencyjne, ani też immanentnie komplementarne, a holistyczny ogląd dziecka nie stanowi prostej sumy dowolnych sensów generowanych przez rozmaitość interpretacji czy wielorakość rzeczywistości. Tożsamość dzieci, czy pojedynczego dziecka, zmienia się raczej w granicach politycznych kontekstów różnych form dyskursu. Stąd różne rodzaje "wiedzy» - matki, nauczyciela, pediatry, pracownika opieki społecznej, psychologa wychowania czy pracownika sądu dla nieletnich - nie egzystują zawieszone w egalitarnej harmonii". Dyskursy dzieciństwa ukazują bogate spektrum interesów dorosłych w odniesieniu do dzieci, koncepcja dziecka jest bowiem konstruktem społecznym, zależnym od kontekstu. Dyskursy te nie wyrastają z próżni, są między innymi rezultatem praktyk kulturowych, które mogą się ujawnić w instytucji, na przykład w działaniach lub treściach przekazywanych $\mathrm{w}$ ramach Biennale. W tym kontekście warto byłoby także przyjrzeć się misji Centrum Sztuki Dziecka, pod którego egidą realizowane jest Biennale: „Centrum Sztuki Dziecka w Poznaniu jest samorządową instytucją kultury. Jego głównym celem jest inspirowanie twórczości dla dzieci i młodzieży, promocja nowych, wartościowych zjawisk artystycznych, popularyzacja i wspieranie rozwoju nowych metod edukacji kulturalnej młodego pokolenia oraz kreowanie wydarzeń artystycznych i edukacyjnych, we współdziałaniu z instytucjami kultury, instytucjami oświaty oraz artystami, edukatorami i menadżerami sztuki" ${ }^{5}$. Misja ta jest egzemplifikacją głównych założeń, na podstawie których planowane są wydarzenia dla dzieci, również Biennale, a tym samym sztuka dla dzieci.

Analiza treści tekstów z katalogów Biennale Sztuki dla Dziecka to materiał na oddzielny artykuł, ale chciałam nakreślić jego potencjał, żeby unaocznić tło oraz dostępne źródła wiedzy dla obserwatorów, którzy brali udział w festiwalu. Ten materiał pokazuje również charakter mojej pracy badawczej - stawianie pytań. Eksplorując przyglądam się temu, co widzę

\footnotetext{
${ }^{5}$ https://csdpoznan.pl/o-nas
} 
w empirii i zastanawiam nad potencjałem zebranego materiału dla generowanej teorii.

Biennale Sztuki dla Dziecka to projekt, który ewaluuje, zmienia się razem $z$ otaczającym go światem społecznym, w tym także z przeobrażająca się wizją dziecka. Jego celem jest zapewnienie młodym obiorcom wartościowych zjawisk artystycznych, zaproponowanie nowych metod edukacji kulturalnej. Jest przestrzenią dla twórczości i kreacji. Biennale to proces tworzenia sztuki dla dziecka, uwzględniający fakt, że zmienia się to, co kryje się zarówno pod hasłem „sztuka”, jak i pod słowem „dziecko”. Procesualność projektu jest widoczna zarówno w przebiegu poszczególnych edycji, ale także, a może przede wszystkim, w drodze, jaką przeszedł przez 46 lat. Wrażliwość na zmieniające się potrzeby, uważność, elastyczność sprawiają, że rozwój biennalowej misji jest widoczny.

\section{OBSERWATORIUM SZTUKI DLA DZIECKA I JAK SIĘ TAM ZNALAZŁAM}

Każdemu z etapów Biennale towarzyszy Obserwatorium Sztuki dla Dziecka, które jest platformą wymiany myśli i doświadczeń na temat twórczości dla młodych odbiorców. Idea Obserwatorium została zapoczątkowana w 2011 roku przez Hannę Gawrońską, która zauważyła, że dotychczasowa formuła konferencyjna przestała wystarczać ${ }^{6}$. Brakowało formuły o bardziej otwartym charakterze, która umożliwiałaby nie tylko namysł nad sztuką dla dziecka, ale także komunikowanie, zarówno w formie pisanej, jak i oralnej, swoich przemyśleń, hipotez, wniosków, ale także odczuć, pierwszych wrażeń, wątpliwości. W 22. katalogu czytamy, że celem stworzenia grupy obserwatorów było zainicjowanie - poprzez konkretne sytuacje oraz propozycje różnych form wypowiedzi - twórczego spotkania, które „pozwala poruszyć ważne tematy związane ze sztuką dla dziecka, a także integrować środowisko działające w tym obszarze" (Krajewska 2019, s. 80).

O Obserwatorium Sztuki dla Dziecka dowiedziałam się na Facebooku. $\mathrm{Na}$ tablicy portalu społecznościowego pojawił się różowy post z grafikami przedstawiającymi uśmiechnięte dzieci. Opis wydarzenia zachęcał do wzięcia udziału w Obserwatorium, rozumianym jako „przestrzeń do spotkania i rozmowy dla osób zainteresowanych kulturą młodych" ". Głównym tematem dyskusji miało być hasło „sztuka jako spotkanie”. Słowo

${ }^{6}$ Zob. wywiad z Hanną Gawrońską (https://biennaledladziecka.pl/news-biennale/inspi rowanie-mlodych).

7 https://www.facebook.com/events/409421403157092/ 
„spotkanie” przykuło moją uwagę, przypuszczam, że głównie ze względu na badania prowadzone przeze mnie do rozprawy doktorskiej ${ }^{8}$. Spotkanie zakłada bowiem interakcje, a ja w badaniu dobieram próbę właśnie opierając się na nich. Co więcej, zarówno w opisie wydarzenia, jak i w tematyce moich dociekań centralne miejsce zajmuje dziecko. I to chyba ten fakt przeważył o decyzji wysłania karty zgłoszenia. Musiałam w niej opisać, jakie mam wykształcenie, jakie są moje zainteresowania związane ze sztuką dla młodych odbiorców i jakie są wcześniejsze doświadczenia dotyczące obszaru kultury dla dzieci oraz dlaczego chcę wziąć udział w Obserwatorium. Ponadto miałam się zdeklarować, w jakich dniach wezmę udział w festiwalu. Najistotniejsza dla mnie była odpowiedź na pytanie dotyczące motywacji. Zdecydowałam, że ze względu na podejście metodologiczne, do którego sięgam w rozprawie — interakcjonizm symboliczny — najchętniej pojechałabym jako obserwatorka, która nie ma jasno sprecyzowanych hipotez, ponieważ chciałam móc przyglądać się wydarzeniu, prowadzić eksplorację. Skupić się raczej na pojęciach uwrażliwiających, które pokazywałyby mi, na co patrzeć, a nie co widzieć (Blumer 2007). Oczywiście, na moją perspektywę wpływały prowadzone przeze mnie badania, a w szczególności problemy, które zaczynały się wyostrzać. Ukierunkowywały one moją uwagę $\mathrm{w}$ określony sposób. Niewątpliwie istotny był również inny fakt z mojego umiejscowienia biograficznego. Oprócz badaczki pełnię także rolę nauczycielki. Codzienne interakcje z uczniami oraz stykanie się $z$ tym, czym jest edukacja i jak działa polski system edukacji, miały wpływ na moją uprzednią wiedzę.

Obserwatorium Sztuki dla Dziecka to integralny element Biennale od pięciu lat. Jest to wydarzenie o interdyscyplinarnym charakterze, w którym mogą się odnaleźć osoby pełniące różne role społeczne. „Biennale Sztuki dla Dziecka to szeroki wybór najciekawszych, precyzyjnie wyselekcjonowanych wydarzeń z obszaru sztuki dla młodych odbiorców. To zarówno warsztaty twórcze, jak i teatr, muzyka, literatura, film, instalacje, performance, malarstwo. Pod skrzydłami Biennale integrują się wszystkie dziedziny artystyczne i mimo tego, że skierowane jest przede wszystkim do dzieci i tworzone $z$ myślą o nich, służy także artystom, edukatorom, animatorom, nauczycielom, studentom, naukowcom i krytykom" (Gawrońska, Krajewska 2015, s. 106). Ta różnorodność była także widoczna w ogłoszeniu Obserwatorium. Pod hasłem „kogo szukamy” znalazły się zarówno osoby zainteresowane pisaniem o sztuce dla dzieci; studenci i ba-

\footnotetext{
${ }^{8}$ Temat rozprawy to: „Głos dziecka jako wyraz podmiotowości w perspektywie socjologiczno-antropologicznej”.
} 
dacze (nie tylko ci doświadczeni, także dla młodych przewidziane było miejsce); dziennikarze; artyści, a także animatorzy różnych dziedzin sztuki, którzy wyrażali chęć rozmowy o wydarzeniach Biennale. Propozycja była skierowana do osób $z$ doświadczeniem $\mathrm{w}$ danym zakresie, ale była także otwarta na ludzi, którzy tematem interesują się od niedawna ${ }^{9}$.

Kuratorkami projektu były Anna Czernow i Joanna Żygowska. To one podjęły decyzję o doborze członków Obserwatorium. W późniejszych rozmowach zdradziły, że istotnym elementem, który wpływał na ich wybór, była deklaracja dotycząca dni festiwalu, w których kandydat lub kandydatka mogliby brać udział. Kuratorkom zależało bowiem, żeby dobrać stały zespół o silnym trzonie, który będzie miał możliwość towarzyszenia dyskusji od początku do końca. Nie wykluczało to wizyt gości, którzy chcieli dołączyć na krócej.

Ostatecznie zespół tworzyło 14 osób, 13 kobiet i jeden mężczyzna (w tym trzy moderatorki: Anna Czernow, Joanna Żygowska oraz Magdalena Majewska). Osoby te pełniły różne role społeczne, które są jak rozumiem za Florianem Znanieckim (1984, s. 530-531 - przypis 5) „systemem normatywnych stosunków między jednostką a częścią jej środowiska społecznego. System taki wyznacza tę część środowiska, ten «krąg społeczny», z którym jednostka jako "osoba społeczna» ma być normatywnie związana; warunkuje jej "jaźń społeczną», tj. obraz tego, czym winna być dla innych i dla siebie $\mathrm{w}$ danej roli jako istota cielesna i psychiczna; ustanawia jej «stan socjalny», czyli zespół praw, jakie ma jej przyznawać dany krąg społeczny; oraz ustala jej "funkcję społeczną", czyli zespół obowiązków, których wykonania dany krąg może się od niej domagać. Role, odgrywane przez różne jednostki w pewnej zbiorowości, zazębiają się o siebie; zależność innych ról od danej roli stanowi o jej znaczeniu społecznym”. Dzięki dostarczonym biogramom można zrekonstruować listę ról, które członkinie zespołu uznały za istotne z punktu widzenia celów projekty (same decydowały bowiem, jaka informacja znajdzie się obok ich nazwiska. Obserwatorium składało się z: literaturoznawczyń (2 wskazania), badaczki literatury dla dzieci i młodzieży, popularyzatorki nauki, tłumaczek (3 wskazania), redaktorek ( 2 wskazania), polonistyki, teatrolożki, doktorantek (2 wskazania), filmoznawczyni, pisarek (2 wskazania), dramaturżki, socjolożki, antropolożki, pedagożki, filolożki, dramatopisarki, teatrolożki, pedagożki teatru, koordynatorki projektów społecznych i edukacyjnych, dziennikarki, prezeski i członkiń polskiej sekcji IBBY (International Board on Books for Young People) (3 wskazania), absolwentki

${ }^{9}$ https://www.facebook.com/events/409421403157092/ 
studiów podyplomowych Literatura i Książka dla Dzieci i Młodzieży na Uniwersytecie Warszawskim, feministki, weganki, rowerzystki. Z biogramów możemy się także dowiedzieć, jakie działania tych osób są istotne z punktu widzenia pełnionej przez nie roli obserwatora, na przykład publikacja artykułów naukowych/ książki; pisanie o czytaniu z dzieckiem na blogu; inicjowanie oddolnej społecznej akcji czytelniczej Warszawa Czyta, współprowadzenie dyskusyjnego klubu książki, prowadzenie kreatywnych warsztatów dla najmłodszych oraz szkoleń metodycznych dla nauczycieli i bibliotekarzy; współpraca z Centrum Sztuki Dziecka w Poznaniu; zajmowanie się metodologią badań z dziećmi; prowadzenie strony na Facebooku.

Każde Obserwatorium było inne, nie tylko dlatego, że festiwal ewoluuje czy zmienia się jego hasło przewodnie, ale przede wszystkim ponieważ obserwatorami są co roku inne osoby. To od ich zainteresowań, kompetencji i doświadczeń zależy kierunek, w jakim podąży Obserwatorium. „W tym roku o biennalowych wydarzeniach uczestnicy rozmawiali z perspektywy badań literaturoznawczych, socjologicznych, praktyki edukacyjnej, artystycznej oraz doświadczeń związanych z animacją kultury dziecięcej, produkowania i programowania wydarzeń artystycznych dla młodych odbiorców" (Krajewska 2019, s. 80). Zespół był różnorodny, tworzyły go osoby w różnym wieku, o różnych doświadczeniach czy umiejscowieniu społeczno-biograficznym, elementem wspólnym była niewątpliwie płeć, zespół był sfeminizowany. Ale tym, co tak naprawdę łączyło wszystkich uczestników, było zainteresowanie dzieckiem oraz sztuką do niego adresowaną. To ten temat sprawił, że kilkanaście osób codziennie wieczorem prowadziło wielogodzinne rozmowy, dzieliło się swoimi wrażeniami z wydarzeń, w których uczestniczyło, poddawało pod dyskusję swoje przemyślenia, wątpliwości, zastrzeżenia. Rozmowy te koncentrowały się wokół takich tematów jak: rola sztuki, podmiotowość, etyka i komunikacja. Ich obserwacja pokazała, jak bardzo te tematy są ze sobą powiązane, jak odpowiedź na jedno pytanie jest uwikłana w inne. Na wieczorne debaty zapraszani byli artyści, osoby zajmujące się sztuką dla dziecka, twórcy książek, czasopism, reżyserzy. Spotkania z artystami odbywały się także w ciągu dnia, w trakcie festiwalu, nie zawsze przyjmowały oficjalny charakter. Każdorazowo jednak była przestrzeń na rozmowę, zadawanie pytań, dyskusję.

\section{OBSERWOWANIE OBSERWATORIUM}

Moja funkcja na festiwalu 22. Biennale Sztuki dla Dziecka od początku była jasno określona - byłam obserwatorką. Atrybutem, który potwierdzał ten fakt, był identyfikator, który nadawał tej roli instytucjonalne umo- 
cowanie. Prowadziłam obserwację jawną, uczestniczącą. Moim zadaniem było przyglądanie się wszystkim wydarzeniom podczas festiwalu oraz branie w nich czynnego udziału. Obserwatorium było jednym z nich. Z jednej strony współuczestniczyłam w tym projekcie, $z$ drugiej zaś obserwowałam go. Swoje spostrzeżenia spisywałam w dzienniczku badacza. Z członkami zespołu rozmawiałam nie tylko podczas oficjalnych dyskusji w Zamku w Poznaniu, który jest siedzibą Centrum Sztuki Dziecka, ale także pomiędzy wydarzeniami, przy wspólnym posiłku, na nieformalnych spotkaniach. Moim zdaniem, decyzja kuratorek projektu dotycząca wyboru osób, które mogą brać udział w całym festiwalu, umożliwiła powstanie prawdziwego zespołu. Staliśmy się wspólnotą. Potwierdzeniem była obserwacja grupy na Finnale Biennale (spotkanie twórców projektu oraz pracowników Centrum Sztuki Dziecka w Poznaniu z członkami Obserwatorium, a jego założeniem była rozmowa na temat festiwalu oraz całego projektu, omówienie wniosków, zastanowienie się nad potrzebnymi zmianami). Widać było zażyłość, bliskie relacje między członkiniami (na Finnale obecne były tylko kobiety), chęć rozmowy i spędzenia wspólnie czasu. Zauważalna była także atmosfera zaufania, otwartości na różne opinie. Moim zdaniem, decyzja o tym, że nie na każde spotkanie Obserwatorium przychodzą pracownicy Centrum, sprawiła, że uczestnicy mogli swobodniej wyrażać swoje opinie, bez obawy, że kogoś zranią lub urażą. Często na spotkaniach wypowiadane były pierwsze wrażenia $z$ jakiegoś wydarzenia. Zazwyczaj były one bardzo nacechowane emocjonalnie. Już sama werbalizacja odczuć była początkiem pewnej pracy nad opinią. Kolejnym krokiem była argumentacja, rozmowa $z$ innymi członkami na dany temat, uzasadnianie swojego zdania. W ten sposób dojrzewały większe pomysły, które stawały się przedmiotem szerszej debaty. Uważam, że dopiero tak przepracowana myśl powinna trafiać dalej, czyli do reżyserów, producentów, twórców. Idea, żeby móc dojrzeć, potrzebuje czasu, miejsca i przestrzeni do kwestionowania założeń. Wszystkie te elementy zapewniało Obserwatorium.

\section{SUBIEKTYWNE ZNACZENIA, CZYLI O PRZEŻYWANIU ZJAWISK NA PODSTAWIE WCZEŚNIEJSZYCH DOŚWIADCZEŃ}

Elementem, który szczególnie zwrócił moją uwagę podczas spotkań, była polifoniczność opinii na te same tematy, co obrazował mój dzienniczek badacza - pełen strzałek ukazujących zależności, zmienność tematów, uwagi na marginesach. Zauważyłam, że poszczególne wypowiedzi są często motywowane wiedzą potoczną lub własnymi doświadczeniami życiowymi, zarówno tymi, które wynikają z pełnionej roli społecznej, ja- 
ki i tymi, które odwołują się do własnych odczuć, emocji, wspomnień $z$ dzieciństwa. Co ciekawe, te argumentacje były jawne, werbalizowane jako uzasadnienie opinii, na przykład jako nauczycielka wiem, że..; ja jak byłam dzieckiem, to...; moje dziecko...

Fenomenologia zwróciła uwagę badaczy na subiektywne znaczenia, wskazując, że są to atrybuty działań ludzkich (Szacki 2006, s. 488). Tematem dociekań stał się nie taki świat, jaki rzeczywiście jest, lecz świat, który obowiązuje dla danych osób, świat z takimi cechami, z jakimi im się zjawia (Husserl 1989). Socjologia fenomenologiczna dokonała nobilitacji potocznego myślenia. „Rzeczywistość społeczna bynajmniej nie jest chaosem, któremu dopiero refleksja teoretyczna nadaje sens i strukturę. Posiada wewnętrzny porządek wprowadzony przez zwykłych ludzi, którzy nie mogliby żyć razem bez rozumienia się i wspólnoty wartości" (Szacki 2006, s. 488-489). Obserwując rozmowy zespołu, zwróciłam uwagę na ogromną rolę intersubiektywności wiedzy. Fakt, iż członkowie zespołu posiadali znacząco różniące się kompetencje i doświadczenia oraz pełnili odmienne role zawodowe, wyostrzał tę intersubiektywność, ponieważ „podstawą wszelkiej interpretacji świata jest zasób uprzednich doświadczeń, zarówno naszych własnych, jak i przekazanych nam przez rodziców i nauczycieli, które w postaci «wiedzy podręcznej» służą jako schemat odniesienia" (Schütz 2012, s. 18). Doświadczenia płynące z wykonywanej roli: artystki, nauczycielki, filolożki, organizatorki projektu czy matki, wybrzmiewały jako argumentacja oczywistych dla wypowiadającego założeń. Często jednak, jak wynikało z moich obserwacji, przekładalność perspektyw nie miała miejsca i niezbędne było wytłumaczenie intencji. Na przykład dlaczego opiekunowie muszą wiedzieć z wyprzedzeniem, że przed spektaklem widownia zostanie poproszona o zdjęcie butów? Doświadczenia rodziców podpowiadały, że nie zawsze skarpetki są „wyjściowe” albo że bez butów, w cienkich skarpetkach może być zimno; nauczycielskie, że organizacja przedsięwzięcia, jakim jest zdjęcie obuwia przez grupę przedszkolną, musi być dobrze przemyślana (kto pomaga dzieciom, gdzie odkładane są buty, skąd wiedzieć po wydarzeniu, czyja jest dana para); artystów, że przecież bez butów dzieciom będzie wygodniej. Podążając za spostrzeżeniem Alfreda Schütza, można samemu dostrzec, że jednostki nie negują oczywistości tego świata, ich wiedza wynika $z$ ich doświadczenia, posiadanych kompetencji, wrażeń na temat obiektów, osób, relacji międzyludzkich. Dlatego właśnie ta wiedza jest intersubiektywna, czyli jest pochodną subiektywności aktorów, mimo że zazwyczaj jawi im się jako obiektywna, ponieważ jest związana z konkretnymi sytuacjami, które aktorzy potrafią opisać i które wydają się im ponadsubiektywne. Człowiek 
naturalnie „bierze w nawias wątpliwość, że świat i jego obiekty mogą być inne niż mu się jawią" (Schütz 2012, s. 34). W trakcie debat Obserwatorium wybrzmiewało wiele opinii, które wynikały z potocznego myślenia. Niemniej jednak sytuacja, w której podczas rozmowy było obecnych tak wiele różniących się od siebie osób, sprawiła, że to co subiektywne było podawane w wątpliwość. Zespół zastanawiał się na przykład nad tym w jaki sposób dzieci mogą sprawczo uczestniczyć w sztuce. Okazywało się, że zdania na ten temat są podzielone. Już samo określenie, co oznacza sprawczość oraz kim jest dziecko, ile ma lat, ujawniało, że perspektywy znacząco się różnią. Celem rozmowy nie było przekonanie pozostałych uczestników do swojej racji, ale umożliwienie wybrzmienia wielogłosu wynikającego z wiedzy, na którą składają się elementy jednostkowych trajektorii biograficznych. Ukazywało to wielowątkowość i kontekstualność tego, kim jest dziecko, jakie ma potrzeby oraz czym wobec tego powinna być sztuka dla dziecka i jak w tym wszystkim nie utracić — no właśnie — sztuki.

Uważam, że podążanie za osobistymi doświadczeniami jednostek, próba odnalezienia argumentacji dla wypowiadanej przez nie tezy jest wartościowa, ponieważ uwrażliwia nas na aspekty, na które być może ze względu na zasób własnego doświadczenia nie zwrócilibyśmy uwagi. Kolaż opinii, który wyłania się z rozmów, może być drogowskazem służącym wszystkim tym osovom, które tworzą coś dla dzieci. Kolaż nie jest tożsamy z montażem, którego założeniem jest połączenie różnych części w całość. Domeną kolażu jest niejednorodność. Jego celem jest uwrażliwianie, skłonienie do podawania w wątpliwość, ostrożność. Nie oznacza to jednak, że twórcy mają obowiązek odnosić się do wszystkich idei, które wybrzmią. Warto jednak, żeby mieli je z tyłu głowy. „Wszyscy aktorzy społeczni są w pewnym sensie teoretykami, kategoryzującymi wiedzę o świecie w imię bardziej efektywnego postępowania w praktycznym świecie codziennych czynności" - czytamy u Schütza (2012, s. XVI).

W Obserwatorium zabrakło mi tylko przestrzeni na wejście $\mathrm{w}$ dialog z dziećmi, na ich udział $w$ debacie. Zgodnie z założeniami nowej socjologii dzieciństwa są one pełnoprawnymi aktorami społecznymi (Mayall 2013; Christensen, James 2017). Ich doświadczenia są wiedzą na temat postrzeganego przez nie świata, i jako takie powinny być traktowane (Mayall 2008). Temat rozmów z dziećmi dotyczących ich spostrzeżeń pojawiał się podczas dyskusji zespołu. Wskazywano jednak na trudności związane $z$ możliwością zrozumienia przekazu formułowanego przez dzieci, na pułapkę władzy związaną ze sztuką dla dziecka, tworzoną jednak przez dorosłego (Mrozińska 2019), na trudności związane z uwikłaniem władzy w partycypację. Podobne wątpliwości ukazuje Martyn Hammersley 
(2017), pisząc na temat paradygmatu childhood studies. Uważam jednak, że rozmowa na ten temat jest istotnym krokiem do poszerzenia kolażu o głosy dzieci. Trzeba jedak pamiętać, z jakimi zagrożeniami i ograniczeniami wiąże się taka decyzja.

\section{SZTUKA DLA DZIECKA JAKO KOLAŻ PROJEKTÓW DZIECIŃSTWA: SZANSE I OGRANICZENIA}

Krytyka myśli fenomenologicznej sprowadza się do zarzutu, że postrzeganie rzeczywistości jako nieskończonej wielości zamkniętych w sobie światów powoduje popadnięcie w skrajny relatywizm (Szacki 2006). $\mathrm{Na}$ takie zagrożenie podczas naszych debat wskazywali także uczestnicy Obserwatorium oraz niekiedy twórcy. Moim zdaniem, podważanie powszechnie przyjętych schematów działań może mieć ogromny wpływ na ostateczny kształt sztuki dla dziecka. Rozwija wyczucie, pozwala dostrzegać różnorodność i niekiedy indywidualność potrzeb, na przykład przez możliwość zauważenia dzieci o wysokiej wrażliwości (Kowerko-Urbańczyk 2019). Jest jednak także potencjalną pułapką, może wywoływać przekonanie, że twórca powinien sprostać potrzebom każdego, a jest to przecież niemożliwe. Za pomocą grafu chciałabym zobrazować wielopłaszczyznowość pytań, które pojawiały się podczas debat Obserwatorium.

Dociekliwość i wrażliwość pozwalają uchwycić istotną problematykę. Werbalizowanie kolejnych wątpliwości, które składają się na kolaż polifonicznych opinii na temat dzieci oraz sztuki do nich adresowanej, może stać się potencjałem zmiany. Dzięki procesualności projektu, jakim jest Biennale, ta zmiana ma szansę się urzeczywistnić. Istotnym kierunkiem zmiany w projekcie dzieciństwa, który zaobserwowałam podczas badań, jest zwrot ku sprawczości, ale sprawczości opartej na współpracy dzieci z dorosłymi. Dostrzegłam też: kierowanie się $\mathrm{w}$ stronę izonomicznego modelu relacji między dorosłym i dzieckiem; odchodzenie od adultystycznego modelu bazującego na wizji dziecka jako osoby niepełnej. Wśród projektów dzieciństwa, które mogły stać za doświadczeniami członków Obserwatorium, czasem pojawiał się także model autonomiczny, ale często był kwestionowany. Dominowało spojrzenie na dzieciństwo jako szczególny etap, który rządzi się swoimi prawami. Nie jest wyłącznie procesem kształtującym przyszłego człowieka dorosłego, chociaż ta wizja wciąż często dominuje w dyskursie dotyczącym edukacji (nie tylko artystycznej) i niewątpliwe wdrukowała się w język. Misja Centrum Sztuki Dziecka oraz podejmowane w związku z tym aktywności są przykładem jawnego działania w rozumieniu Alfreda Schütza (2012, s. 131), który zwraca uwagę także na potencjał 
„dokonania w umyśle teatralnej próby wyobrażenia sobie wielu konkurujących ze sobą, możliwych linii działania" (Schütz 2012, s. 132). Jednak proces projektowania działania zawsze odnosi się do zasobu wiedzy podręcznej aktora spolecznego (Schütz 2012, s. 135), dlatego tak istotne jest zderzenie się z wiedzą osób o odmiennych doświadczeniach życiowych w celu wdobycia tego, co do tej pory było subiektywnym motywem „ażeby". Wybrane przeze mnie podejście metodologiczne bazuje na otwartości na to, co przyniesie interior. Szukanie pojęć uwrażliwiających skłania do zadawania ogólnych pytań, które uszczegóławiają obserwacje ze świata empirii. Taka metodologia umożliwiła mi dostrzeżenie polifoniczności oraz docenienie jej potencjału.

\section{BIBLIOGRAFIA}

Blumer Herbert, 2007, Interakcjonizm symboliczny: perspektywa i metoda, tłum. Grażyna Woroniecka, Nomos, Kraków.

Christensen Pia, James Allison, 2017, Research with Children: Perspectives and Practices: Third Edition, Routledge, London (https://doi.org/10.4324/9781315657349).

Corsaro William A., 2015, The Sociology of Childhood, Sage, Thousand Oaks, CA.

Czernow Anna M., Żygowska Joanna, 2019, Sztuka jako spotkanie, w: 22. Biennale Sztuki dla Dziecka, Centrum Sztuki Dziecka w Poznaniu, Poznań.

Gawrońska Hanna, Krajewska Agnieszka (red.), 2015, 20. Biennale Sztuki dla Dziecka, Centrum Sztuki Dziecka w Poznaniu, Poznań.

Hammersley Martyn, 2017, Childhood Studies: A Sustainable Paradigm?, „Childhood”, t. 24 (1), s. 113-27 (https://doi.org/10.1177/0907568216631399).

Hart Roger, 1992, Children's Participation: From tokenism to citizenship, „Innocenti Essay”, nr 4.

Hart Roger, 1997, Children's Participation: The Theory and Practice of Involving Young Citizens in Community Development and Environmental Care, Earthscan, London.

Husserl Edmund, 1989, Nastawienie nauk przyrodniczych $i$ humanistycznych. Naturalizm, dualizm i psychologia psychofizyczna, w: Edmund Husserl, Fenomenologia i socjologia, Państwowe Wydawnictwo Naukowe, Warszawa.

James Allison, Prout Alan, 1997, Constructing and Reconstructing Childhood, Routledge Falmer, London.

Jenks Chris, 2008, Constructing Childhood Sociologically, w: Mary Jane Kehily (red.), An Introduction to Childhood Studies, McGraw-Hill Education, Maidenhead.

Kowerko-Urbańczyk Marta, 2019, Trzy spotkania z wysoka wrażliwościa w teatrze. Impresje na marginesach, w: 22. Biennale Sztuki dla Dziecka, Centrum Sztuki Dziecka w Poznaniu, Poznań.

Krajewska Agnieszka (red.), 2019, 22. Biennale Sztuki Dla Dziecka, Centrum Sztuki Dziecka w Poznaniu, Poznań.

Kreis Magdalena, 2017, (Inter)aktywności, w: 21. Biennale Sztuki dla Dziecka, Centrum Sztuki Dziecka w Poznaniu, Poznań.

Leszczyński Grzegorz, Żygowska Joanna, 2018, Sztuka jako spotkanie, Centrum Sztuki Dziecka w Poznaniu, Poznań. 
Mayall Berry, 2008, Conversations with Children: Working with Generational Issues, w: Pia Christensen, Alison James, Research with Children: Perspectives and Practices, Routledge, Abington-New York.

Mayall Berry, 2013, A History of the Sociology of Childhood, UCL Institute of Education Press, London.

Mrozińska Magdalena, 2019, Nie odbieraj dziecku sztuki, w: 22. Biennale Sztuki dla Dziecka, Centrum Sztuki Dziecka w Poznaniu, Poznań.

Schütz Alfred, 2012, O welości światów, Nomos, Kraków.

Szacki Jerzy, 2006, Historia myśli socjologicznej, Wydawnictwo Naukowe PWN, Warszawa.

Zalewska-Królak Aleksandra, 2019, Polifoniczny opis roli dziecka w sztuce dla dziecka, w: 22. Biennale Sztuki dla Dziecka, Centrum Sztuki Dziecka w Poznaniu, Poznań.

Znaniecki Florian, 1984, Społeczne role uczonych, Państwowe Wydawnictwo Naukowe, Warszawa.

$*$

https://csdpoznan.pl/o-nas

https://www.facebook.com/events/409421403157092/

https://drive.google.com/file/d/1XqWTJeAa2m2JIB3ql8qVS6cTjlPvz5Ab/view

https://biennaledladziecka.pl/news-biennale/inspirowanie-mlodych/

THE ART FOR THE CHILD OBSERVATORY AS A POLYPHONIC COLLAGE OF PROJECTS OF CHILDHOOD

Aleksandra Zalewska-Królak

(Warsaw University)

Abstract

The researcher describes her experience of participating in the 22nd Biennale of Art for Children. Discussions conducted as part of the meetings of the Observatory, a group created to observe and talk about events as an integral part of the project, show the polyphony of opinions about who is a child and what art is for a child. As Schütz points out, subjective meaning is an inherent attribute of human activities. People experience phenomena on the basis of their previous experiences. According to the premises of phenomenology, the discussions of people from different socio-biographical locations will provide a variety of visions. The author describes how the experience of people who are involved with art for children but who differ in their social and professional roles influences the planning of events for children.

key words: children, childhood, phenomenology, art for children, observation

słowa kluczowe: dzieci, dzieciństwo, fenomenologia, sztuka dla dziecka, obserwacja 